Secciōn DivulGaciōn, REVISIŌN Y ENSAyOS 

ISSN: 1576-0162

http://dx.doi.org/10.33776/rem.v0i58.4843

\title{
Pandemics and Globalisation: Parallel Paths Throughout History
}

\author{
PANDEMIAS Y GLOBALIZACIÓN: \\ CAMINOS PARALELOS A LO LARGO DE LA HISTORIA
}

Nieves Carmona González Universidad Francisco de Vitoria

n.carmona@ufv.es

María Pilar Sánchez Martín Universidad Francisco de Vitoria m.sanchez.prof@ufv.es

Recibido: junio de 2020; aceptado: diciembre de 2020

\section{ABSTRACT}

In this work we offer a historical overview of the pandemics which have troubled humanity over the course of centuries and their economic impact. All of these pandemics share a direct relation to international trade and globalisation. Our aim is to provide a historical reference of previous pandemics and their direct connection to the phenomenon of globalisation.

Keywords: Pandemic, globalisation, history.

\section{RESUMEN}

En este trabajo presentamos un recorrido histórico de las pandemias que han asolado a la humanidad a lo largo de los siglos y sus efectos económicos. El núcleo que conecta a todas las crisis pandémicas guarda relaciōn directa con el comercio y la globalizaciōn. Nuestra aportaciōn es poner en valor la historia como referencia de otras pandemias y su conexión directa con el proceso globalizador.

Palabras clave: pandemia, globalizaciōn, historia.

Clasificación JEL/ JEL Classification: N10, N30, N70. 



\section{INTRODUCTION}

The current coronavirus pandemic (COVID-19) has caused a global crisis which seems to be unprecedented; however, since the year 165 AD there have been a series of devastating pandemics which have taken millions of human lives and caused severe economic hardship and disruption.

What all of these pandemics have had in common is a network of international trade routes produced by globalisation, from the Antonine Plague (165-180 DC), contracted by Roman armies in the Middle East, to the current pandemic originating in China, currently the principal exporter in global trade.

The same mechanisms which favour the transmission of pandemics are the very same which favour the growth of international commerce. One could say that the transmission of viruses is an unfortunate externality of global trade.

\section{SOME BIBLIOGRAPHICAL NOTES ON PANDEMICS}

Within the field of the history of medicine there are any number of studies focussing on the analysis of viruses and bacteria which have plagued humanity throughout history. Of particular note are studies by Maradona (2010), who traces the history of parasitic infection from prehistory to the 19th and 20th centuries; and Wolfe, et al. (2007:279), who analyse 25 of the principal human pathogens originating in the Old World and which were hugely consequential in the conquest of America. The epidemiological model which arose with the Industrial Revolution reached its apogee with changing demographics and medicine in the 19th and 20th centuries (Rigau, 1996:560) when new pathologies appeared such as AIDS (Arrizabalaga 2000:94; Werner et al. 1999:50-51), outbreaks of pneumonia in Asia (Dye et al. 2013) and the reemergence of ancient illnesses such as cholera and tuberculosis, among others (Werner et al. 1999:50-51; Chavers et al. 2007:7).

There are however few scientific studies dealing with pandemics and their economic repercussions, although most find a directly proportional relation between the spread of illness and the movement of goods and people. Gonzalbes and García (2007:9), in their study of the Antonine Plague, show how the expansion of the Roman Empire facilitated communications throughout the known world, from Mesopotamia to Britain, from the Black Forest to the Sahara, resulting in a globalisation of bacilli and bacteria. This 
internationalisation of risks and opportunities was not a new phenomenon (Frenk, 2007:157); the first documented international epidemic took place during the Peloponnesian War, in the 5th century BC (Rosen, 2015:5-7), followed by the Plague of Justinian which devastated the Roman Empire (Porter, 2006:20-22). Le Roy (1973:629) referred to the 14th century Black Death as "microbial unification", metaphorically relating the epidemic with the phenomenon of globalisation. In 1347, Italian merchant ships carried the Bubonic Plague from the Crimea across the Black Sea to Constantinople and on to other European ports in the Mediterranean, thus triggering the spread of the Plague through Asia Minor, the Middle East, North Africa and Europe (Benedictow, 2011: 71).

The late Middle Ages saw the resurgence of commerce as well as a proliferation of pandemics. A study by Wolfe, et al. (2007:281-282) attributed their terrific expansion from the Old World to the Americas because the native population had neither immunity nor resistance to the newly introduced diseases. Similarly, Guerra (1986:42-43) writes that the clash between the Spanish Conquistadores and indigenous peoples represented an epidemiological collision with catastrophic consequences and the principal cause of the depopulation of the Americas. Once again, we find an example of how illnesses can spread dramatically, over the course of almost a century, due to the interconnection of extensive territories.

The Industrial Revolution was a period of the most significant economic, technological and social change since the Neolithic period. It was also an era of great epidemiological transmission; the Russian Flu (Maris, 2011:30-39; García, 2017:89-92), the Hong Kong Plague (Lowson, 1897:45), the Spanish Flu (González, 2005; Correia et al. 2020:1; Barro et al. 2020). All of this scholarship inevitably leads to parallels today, as we look to the economic repercussions during and after the pandemics of the past.

The pandemics of the late 20th century spread rapidly, most notably the Asian flus (Bueno et al, 2006:19) and the Hong Kong flu, spread by American soldiers returning from Vietnam (CDC, 2019). Late in the century there appeared a new threat, AIDS (Acquired Immune Deficiency Syndrome) which spread across the world and especially in Europe coinciding with the consolidation of the European Union (Grmek, 1992:160-171).

In this work we begin with a historical review of pandemics later relating the different stages of globalisation with the most significant epidemiological episodes and finally, we will analyse the economic impact of these pandemics.

\section{AN OVERVIEW OF PANDEMICS THROUGHOUT HISTORY}

The first great known pandemic of Rome, known as the Antonine Plague, took place in $165 \mathrm{AD}$. It appears to have originated in Ethiopia, from where it spread to Asia and on to Seleucia, one of the largest cities in the world during the Roman Empire, located Mesopotamia on the banks of the Tigris River. 
Up to that time the Roman population enjoyed a relatedly good quality of life. The autobiography of the Emperor Marcus Aurelius describes the situation: "In addition, there was such a heinous plague that the bodies had to be removed from the city in vehicles and wagons. It was then that the Antonines imposed strict laws on burials and sepulchres, even prohibiting that individuals build their own tombs in their villas, a disposition that remains today. The plague consumed many thousands and many of the illustrious" (Gozalbes et al., 2007:12)

Gozalbes et al. (2007) conclude that the crisis of Rome was greater than the pandemic; a crisis of subsistence and rising prices that undermined the health of the population, making them vulnerable to disease. Thus, they point to the effects of globalisation in the transmission of pandemics. The economic consequences were terrible. Economic activity was virtually paralysed by a shortage of labour. In fact, agreements were made with the enemies of Rome for them to establish themselves within the Empire as colonists and bring land back under cultivation.

The historian Barthold Georg Niebuhr (1844:197-200) in his History of Rome affirms that the reign of Marcus Aurelius (161-180) was the point of inflection point which destroyed part of the advances made in science, literature and the arts. However, the historian Edward Gibbon (1996) gives less importance to the epidemic in the crisis, highlighting political and economic factors.

Sales (2020) has perceived parallels between the COVID-19 pandemic and the Plague of Justinian which ravaged the world in 541 AD. The origin was again Africa, reaching Egypt and from there to the rest of the Mediterranean. One possible origin was Rhapta, a commercial enclave on the southeast coast of Africa, under control of the Arabs, and a source of the ivory in high demand in the Byzantine Empire to produce ornaments. The pandemic spread quickly throughout the Byzantine Empire, leaving towns and cities uninhabited. It is estimated that mortality reached 10,000 people per day (Harvard University, 1935).

The economic effects were devastating; the lack of tax revenues weakened Byzantium in the face of barbarian and Avar invasions. Multiple wars exhausted the financial resources of both the Byzantine and Persian Empires, facilitating the Arab conquests of the 6th century.

In the year 735 AD, Japan suffered what is known as Japanese Smallpox, with a mortality rate of approximately $35 \%$ of the population. The illness was again directly related to trade, in this case, with Korea. The crisis produced a mass exodus from the countryside and the abandoning of the majority of crops. To address the problem policies were implemented granting ownership of the land to those who cultivated it, tax exemptions and financial injections to fund the construction of temples (Farris, 1985:75-76)

But the pandemics most reminiscent of today is the Black Death of the 14 th century, which reduced the European population by a third. The effects were 
truly devastating. According to historians, the Iberian Peninsula lost between $60 \%$ and $65 \%$ of its population (Benedictow, 2011:505).

Until the 14th century, the economy had experienced notable growth, especially in Italy and Flanders. Between 1050 and 1300 the population had grown, and agricultural output was unable to meet the growing demand. Forests were cleared to bring more land under cultivation and create new settlements, and livestock farming was intensified to produce surplus goods for trade. In this way, new towns were added to commercial routes. Maritime transport increasingly facilitated commerce on a larger scale with trade routes connecting Venice and Genoa to Constantinople and the Crimea, Alexandria and Tunis to London and Brussels, etc. All of which would facilitate the spread of the epidemic (Benedictow, 2011:78).

The plague was a zoonosis, that is, an illness which passes from animals to humans. Large commercial cities became the focal points of infection and from these the epidemic rapidly spread to distant commercial and manufacturing centres via extensive land, sea and river trade and pilgrimage routes.

The European population fell from some 80 million to 30 million people. Benedictow (2011:380) synthesises and analyses historical data of each of the regions affected by the Black Death and collects several works on the pandemic written over the last forty years. Findings show that the plague not only shook the social and economic foundations of the Old World, it changed the course of human history forever.

In the early 16th century, Spanish colonisers brought Cocoliztli to America. Between 1519 and 1600, the indigenous population of Mexico dropped catastrophically from between 15 to 30 million to 2 million (Acuña et al. 2004:1). Research by scientists at the Max Planck Institute at Harvard University and the Instituto Nacional Mexicano de Antropología e Historia (Vågene et al. 2018:524-525) identified salmonella, possibly introduced into Mexico by animals brought by the Spanish, as the pathogen responsible.

In the 17th and 18th centuries, apart from the Italian Plague (1629-1631) and the Persian Plague (1772-1773) causing three million deaths, epidemics did not strike again until the early 19th century, specifically 1817.

From the Gulf of Bengal, a cholera epidemic spread rapidly, first to Turkey and Arab states and later to the rest of the world via British trading routes. The principal cause appears to have been the rapid and disordered growth of urban areas and a deficient water supply system which failed to filter wastewater. From 1817, cholera pandemics would reappear seven more times in the 19th and 20th centuries.

At the end of the 19th century, the Russian Flu and the Plague took a terrible toll on the population and stunted economic growth in the affected countries.

On November 26th, 1889, the press reported on thousands of people taken ill in Saint Petersburg. It became known as the Russian Flu. The contagion was very rapid, spreading across Europe in only six weeks and to the rest of the world within six months (Maris, 2011:30-39). The Industrial Revolution had led 
to improved transportation networks, shortening distances and allowing the disease to spread with unprecedented speed. The measures adopted by many governments to combat the contagion were similar to those imposed to deal with COVID-19: the closure of schools and universities. Hospitals were unable to cope with the number of patients and temporary field hospitals were set up in gardens and patios. Public services were severely impacted, especially tram and train service, post, telegraph and also funeral services, among many others. Industry, commerce, cafés and theatres saw a steep decline in the number of both clients and healthy employees (Garcia, 2017:27).

In 1894, the bubonic plague reappeared in Hong Kong. The British and Chinese authorities were unable to agree on the measures to be adopted. While the British recommended ventilating homes, burning certain household utensils and to disinfect building facades with lime, Chinese doctors recommended not ventilating and natural remedies (Lowson, 1897:48-49).

The epidemic was finally brought under control, but with recurrent seasonal outbreaks in 1910 and 1911, taking the life of sixty thousand people in northeast China where the mortality rate of those infected reached $100 \%$.

In 1918, the misnamed Spanish Flu caused more deaths in 24 weeks than AIDS in 24 years and more deaths in one year than the Black Death in 100 (González, 2005:464).

The epidemic began in the United Sates, although the precise origin has never been identified. The press at the time pointed to Spain as the source: "It was called the Spanish Flu because it was thought to have been brought by Spanish immigrants but in reality the epidemic originated in China and spread around the world" (Enciclopedia Barsa, 1988;8:400).

"Spain had few cases before March but as the country was neutral during the war, the Spanish press closely reported the epidemic, especially as the King Alfonso XIII fell gravely ill. It became known as the "Spanish Flu" since during the war newspapers in belligerent countries were under strict military censorship and could not report on these events except in Spain. Thus, news about the epidemic appeared only in Spanish newspapers, giving the impression that Spain was the only country affected by the epidemic" (Murillo, 2011:464).

"In 1918, world leaders, in order to halt the spread of widespread pessimism, resorted to what had served them well on no few occasions in the past: control the flow of information and reports on an illness which was spreading without control... press censorship had successfully kept this information from the public except in Spain, a neutral country, which freely published in October that the civil population of countries around the world will falling ill and quickly dying without any means to stop the contagion. Thus, people began to know of the illness as the Spanish Flu" (Murillo, 2011:464).

At that time, the response by governments was very limited. As today, the newspapers of the time announced miracle cures, even encouraging people to smoke, thinking that nicotine would kill the virus. When measures were finally adopted it was too late, explaining the high number of deaths. Finally, orders 


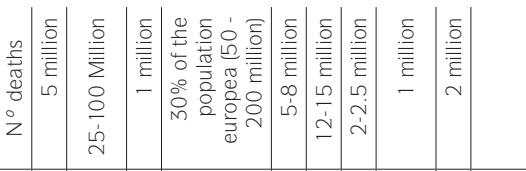
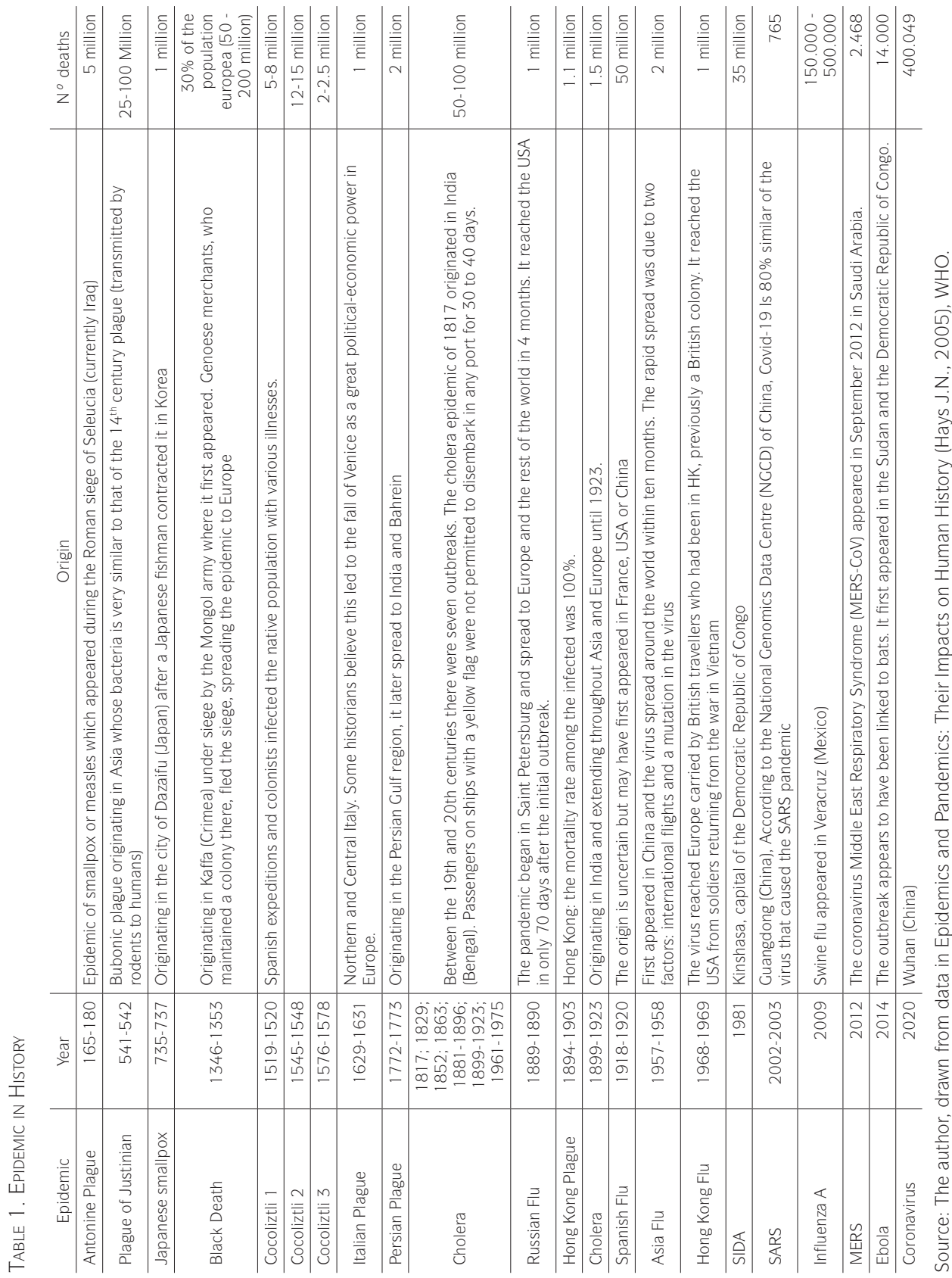
were given to disinfect public transport, factories and theatres, closing schools and universities and requiring the use of masks by public employees.

According to a study by Sandy Mackenzie and Johannes Wiegand for the International Monetary Fund (2006: 76), industrial production and business activities suffered a drop in 1918 at the height of the epidemic but later recovered quickly. The Federal Reserve Bank of St. Louis (2007:19) estimated the drop to be between $40 \%$ and $70 \%$ during the epidemic, while retail food sales fell by a third. The most affected companies were those in services sector; however, other businesses, specialised in medical products, experienced notable growth.

In 1957, at the height of the Cold War, there was a new outbreak of Asian Flu in Yunnan province, quickly spreading to Singapore, Taiwan, Japan, the United States, India, Australia and Spain, among other countries. Fortunately, the World Health Organisation (WHO) had been researching the virus for some time and had produced a vaccine. Over 34 million vaccines were distributed that year, thus accounting for the relatively low mortality rates for Asian Flu (Bueno et al., 2006:21).

The last pandemic of the 20th century took place in 1968, again with its focal point in Hong Kong, hence the name: the Hong Kong Flu. The contagion spread to the United States, brought by American soldiers returning from Vietnam; the mortality rate of the pandemic was high compared to Europe. Caused by the Influenza A virus, the pandemic caused one million deaths worldwide and approximately 100,000 in the United States (CDC, 2019).

\section{The PARAdOX OF ECONOMIC GLOBALISATION}

Globalisation can be understood as the growing interdependence of states, cultures and societies. Although globalisation has become a social and cultural phenomenon, it is in reality principally an economic process, characterised by the integration of different national economies. In fact, the International Monetary Fund (IMF) speaks of globalisation as "a growing economic interdependence of countries all over the world caused by the increasing volume and variety of overseas transactions of goods and services, international capital flows and the accelerated and generalised expansion of technology" (Stiglitz, 2003:216).

There is no consensus among social researchers on what the phases of globalisation are, or even when the process began. Some theories (Bernstein, 2010; McNeill and McNeill, 2010) mark the beginning of globalisation with the birth of early civilizations; others claim that the globalising process began with the first overseas colonial empires (Christian, 2007; Robertson, 1990; Robertson, 2005. The third theory places the globalising start during the I Industrial Revolution (Langhorne, 2001; Frieden, 2013). The last position considers that globalisation began after the IIGM (Castells, 2000; Conversi, 2010). 
It would appear that globalisation is a new phenomenon, exclusive to the 21 st century. However, if we understand the concept of globalisation as the greater interconnection between regions and economies, we can identify a process of four phases stretching from the Roman Empire to our current capitalist system (Carmona, 2015:24).

The First Globalisation dates from the Roman empire, which built roads, bridges and aqueducts, establishing a single legal system and currency. "The Romans had the instinct and the intention to extend their dominion over the entire inhabited world. This was a true globalising intent." (Le Goff, 1982:5358).

During this first globalised phase, the Antonine Plague and the Plague of Justinian, supposed a change in the economic fortunes of the Roman Empire. Until then the Romans enjoyed a healthy, prosperous economy but the high mortality rate led to a loss of economic resources which directly impacted the production of goods and services with the social and economic deterioration of the population.

During the Second Globalisation, the age of discovery and the colonialism, when three epidemics of Cocoliztli and the Italian Plague took place. Spanish Conquistadores brought to America illnesses which were unknown in the New World. The devastating mortality rates among the indigenous population no doubt facilitated the conquest of the vast territories.

By 1771, at the dawn of the I Industrial Revolution, the Third Globalisation was under way, to be consolidated over the course of the 19th century. Liberalism supplanted mercantilism and democratic systems of government began to take hold. Both economic liberalism and political democracy both arose at the end of the 18th century, particularly in 1776, the year Adam Smith published "The Wealth of Nations" and of the Declaration of Independence in Philadelphia, laying the foundations of political liberties. This Third Globalisation was characterised by, firstly, the liberalisation of commerce thanks to the repeal of the "Corn Laws" in England and the signing of a free trade agreement between England and France in 1860; secondly, european imperialism in Africa and Asia created new currents of international trade, capital transfer and human migration. This process of globalisation would facilitate the spread of Plague, Cholera and the Russian Flu epidemics. Cholera first appeared in the Ganges River basin, in India, where the illness was endemic, spreading along trade routes to Russian in 1830. A few years later it would appear in Western Europe where insalubrious urban conditions, especially the absence of effective sewerage systems, would allow the epidemic to spread. In 1889 , some 1,500 kilometres of the Central Asian Railway, also known as the "TransCaspian Railway" were completed, connecting the city of Bokhara with Russia and so to the rest of the world (Smith, 1995:60).

The Third Globalisation was interrupted by the First World War and the subsequent economic crises of the 1920's. The Spanish Flu of 1918 paralysed the world, striking with particular virulence at the young, thus reducing the labour force available for work in agriculture and industry. 
Successive stages of globalisation led to a consolidation of the interconnection of countries, facilitating both trade and the transmission of viruses. The Fourth Globalisation, after the Second World War, saw great efforts to establish international financial and commercial institutions, including the IMF, the World Bank and the expansion of free trade (General Agreement on Tariffs and Trade, GATT).

With the fall of the Berlin Wall in 1989 and the collapse of the Soviet Union in 1991, the process of globalisation accelerated, culminating in the creation of the World Trade Organisation (WTO) in 1995. In this context, a series of pandemics such as the Avian flu, HIV, SARS, Influenza A, MERS and Ebola, afflicted the entire world, undermining human and economic development.

It is interesting here to not the affirmation of Yale University Professor of the History of Medicine, Frank Snowden (2019:6): "Epidemic diseases are not random events that afflict societies capriciously and without warning, On the contrary, every society produces its own specific vulnerabilities. To study them is to understand that society's structure, its standard of living, and its political priorities." As we see, pandemics are not only an issue of human health and public health care systems but have significant socio-economic impact, affecting strategies of political economy with national and international implications.

In the area of international economics it is well known that trade creates interdependence, producing externalities which can be both positive and negative. Hence the need to establish coordination mechanisms to internalise negative externalities of economic interdependence (Díaz-Roldān and Perote, 2015: 4-5). In the case of the COVID-19 pandemic, "the engine of growth" has gone into reverse: China halts production due to the epidemic originating in Wuhan and impacts commercial partners practically all around the world. Given that all economies are now interdependent, if a country enters a crisis its level of imports will fall, and commercial associates will also reduce their purchasing from the affected country (China). This will cause a contraction of exports, a fall in GDP and difficulties to import goods; a vicious circle of impoverishment leading to a contraction of the global economy. The OECD (2020) notes that one of the most significant problems has been the origin of the epidemic itself since China is a key player in the services and raw materials sector, causing rapid and direct contagion to the rest of the global economy.

Just as cooperation and coordination mechanisms between countries are essential for international trade, addressing the economic and social impact of the COVID-19 pandemic requires international policy coordination to ensure the effectiveness of measures taken around the world. The OECD (April 2020) noted some areas for coordination, such as the international data collection on the profile of the virus, the affected population, means and routes of transmission and remedies for the design emergency protocols to be adopted; processes of regulatory alignment and mutual recognition in order to accelerate administrative procedures (accepting product certifications of other jurisdictions, for example) and, finally, to limit regulatory barriers to the trade 
of essential products: personal protection equipment, medical devices and new diagnostic tests and treatments.

The secretary general of the OECD Angel Gurría (OECD, 2020), in the G20 summit on COVID-19, proposed a global Marshall Plan to address the impact of the pandemic and to prepare citizens for future crises. The proposals were specifically focussed on recapitalising public healthcare and epidemiological systems; to activate all macroeconomic levers: monetary, fiscal and structural policies; lift existing commercial restrictions, especially applying to medical supplies; support poor and developing nations; share and apply best practices to support workers and all people, employed and unemployed, especially the most vulnerable; provide assistance to companies, especially small and medium enterprises (SMEs); and establish support packages for the most affected sectors.

The challenge will be how to face a prolonged emergency since, among others, problems of liquidity can quickly become solvency problems, undermining the ability of certain business sectors to survive (Serrano, 2020:113).

\section{FROM PANDEMICS TO ECONOMIC CRISES}

In the previous sections we have seen the manner in which pandemics, epidemics that spread beyond the border of the country where they initially occur, follow the same international trade and travel routes. The loss of population, healthcare costs and the fall in production in some sectors produces an economic recession which, over time, leads to an economic crisis. In order for this to occur, there must be a high mortality rate, enough to cause a drastic reduction in the workforce; a collapse in public healthcare systems leading to runaway deficits; the lack of effective containment mechanisms (medication, vaccines); that the contagion extends over time, ultimately requiring the confinement of the population causing economic paralysis.

In the COVID-19 crisis public healthcare systems have been overwhelmed and the confinement of the population has resulted in a brusque halt in productive activity. However, some studies of other pandemics show that early, restrictive, non-medical measures can slow the rate of contagion and mortality and can even have positive economic effects in the medium term. The study by Correia et al. (2020:2-5) analyses the effect of the 1918 Spanish Flu on the US economy; the findings suggest that pandemics can have high economic costs, but if non-medical measures are applied in time and in a manner that reduces mortality they can mitigate the adverse economic impact of the pandemic; ultimately, the study shows that one year later, regions which experienced the highest grow were those which implemented the strictest confinement measures and thus had lower mortality rates.

Barro and Ursúa (2008:256-259) conducted a study on the macroeconomic impact in times of disaster (when there is an accumulated drop in one or several years of $10 \%$ or more in the per capita GDP or real 
per capita consumption) since the year 1870. They reach the conclusion that the principal global economic crises, by impact were: the Second World War, the First World War and the Great Depression (possibly reflecting the flu of 1918), and events subsequent to the Second World War such as the Latin American debt crisis and the Asian crisis. The found 87 crises in consumption and 148 for GDP, which implies that the probabilities of a disaster to be $3.6 \%$ per year. The scope of disasters averaged 21-22\% with an average duration of 3.5 years. Comparisons between drops in consumption and in GDP largely coincide. However, the average fractional fall in consumption exceeds that of GDP during wartime but is similar during crises other than war (for examples crises resulting from a pandemic).

A recent study by Barro et. al., (2020), recalling the findings of previous studies, point to a possible relation between the Spanish Flu of 1918 and COVID-19 in terms of high mortality rates (although evidently medical advances have taken place) and economic contraction. The influenza epidemic of the early $20^{\text {th }}$ century resulted in substantial short-term reductions in the yields on shares and government bonds, as well as falls in GDP comparable to the current situation.

The IMF (April 2006:74) examined the possible impact of an avian flu epidemic on supply and demand, including external demand and calculated that, if $25 \%$ of the workforce becomes ill or is confined for six weeks, with a mortality rate of $0.6 \%$ of the workforce, aggregate labour inputs will fall by approximately $13 \%$ during the quarter and some 3\% for the year; the sharpest drop since the Second World War (1939-1945). According to the Cobb-Douglas production function, with a coefficient of $0.6 \%$ for labour inputs, the fall in GDP would be approximately $8 \%$ for the quarter and $2 \%$ annually (IFM, 2006:74).

Obviously, the effects on countries are never homogeneous. As a result of COVID-19, according to IMF (october 2020: 9-11)) global growth will be -4.4\% in 2020 and reach 5.2\% in 2021. China will be the only global economy with positive growth by 2020 (1.9\%) 8.2\% in 2021. For the United States, the MFI forecasts a contraction of $-4.3 \%$ in 2020 and growth of $3.1 \%$ by 2021 . For the euro area the contraction in growth will be -8.3\% in 2020 and will show growth of $5.2 \%$ by 2021 . However, the report points to significant differences between European countries. While for Germany it expects a contraction of $-6 \%$ for the Spanish economy augurs a fall of $-12.8 \%$. France $(-9.8 \%)$ Italy $(-10.6 \%) 2020$.

In the specific case of Spain, García Delgado (2020) points out three aspects as main responsible for: the composition of the productive fabric, the high proportion of freelancers and micro-enterprises and the mismatches in the labour market.

Deloitte (2020) highlights three direct impacts on the global economy: (i) the impact on production. The deceleration of production in China has led to a reduction in imports, significantly affecting its principal suppliers, South Korea and Japan; (ii) the impact on the supply chain. Many companies rely 
on raw and intermediate materials imported from China, which are difficult to substitute in the short term, and (iii) financial impact. Risk aversion tends to contract financial markets. The delays in deliveries has slowed production creating financial difficulties for companies carrying high levels of debt.

Experts at the IMF (october 2020,7) believe that the economic consequences depend on factors which are difficult to predict: the evolution of the pandemic, the effectiveness of containment measures, the development of cures or vaccines, the scope of changes in economic activity, changes in consumer spending habits, changes in behaviour, confidence and, finally, the volatility of the price of basic goods.

Despite the above, not all pandemics result in economic crises. Walter Scheidel (2020), historian at Stanford University, points to the $14^{\text {th }}$ century Plague as one of the four great levellers in history. That pandemic caused a labour shortage which altered power relations between landowners and labourers. Similarly, European reconstruction after the First and Second World Wars, which left nations and economies devastated, led to the greatest wealth levelling process in Western history between 1945 and the 1970's. A trend that would go into reverse in the following four decades. Nevertheless, the majority of pandemics have historically had devastating economic consequences and the hope is we can learn to prepare for, prevent and effectively deal with future pandemics.

\section{CONCLUSIONS}

Throughout this work we have provided a historic overview of the principal pandemics and how globalisation has favoured their propagation across the world.

Among these are the common origin of many pandemics is China, from the Antonine Plague (165 AD) to COVID-19. In the absence of scientific or epidemiological studies, the reasons for this are twofold: firstly, China has always been a vast commercial centre since Antiquity, and secondly, animal markets have always been part of the culture. Most studies point to the spread of viruses and bacteria from animals to humans as the principal cause of epidemics.

Additionally, despite the benefits of globalisation one of its negative externalities is the rapid transmission of epidemics, leading to global pandemics. Improved and extensive transportation networks have, throughout history, facilitated the rapid propagation of contagious diseases.

In addition to the cost in human lives and the strain on public healthcare systems, pandemics also have devastating economic and social impact, although in some cases the crises caused by pandemics have served to level economic differences. This is a problem that affects all countries and measures to deal with and prevent future pandemics must be necessarily be undertaken collectively. 
Once again history repeats itself; let us take this opportunity to learn from it.

\section{REFERENCES}

Acuña Soto, R.; Stahle, D.W.; Therrell, M.D.; Griffin, R.D.; Cleaveland, MK. (2004): "When Half of the Population Died: the Epidemic of Hemorrhagic Fevers of 1576 in Mexico", FEMS Microbiology Letters, Vol 240, 1-5.

Arrizabalaga, J. (2000): "Las enfermedades emergentes en las postrimerías del siglo XX: El SIDA”, Política y Sociedad 35, 93-100.

Barro, Robert J. and Jose F. Ursúa (2008): "Macroeconomic Crises since 1870.” Brookings Papers on Economic Activity 39 (Spring), 255-350.

Barro, R. J., J. F. Ursúa, and J. Weng (2020): "The Coronavirus and the Great Influenza Pandemic: Lessons from the "Spanish Flu" for the Coronavirus's Potential Effects on Mortality and Economic Activity", Working Paper 26866, National Bureau of Economic Research.

Benedictow, Ole J. (2011): La Peste Negra, 1346-1353: La historia completa, Akal, Madrid.

Bernstein, W. (2010): Un intercambio espléndido. Cómo el comercio modeló el mundo desde Sumeria hasta hoy, Ariel, Barcelona.

Bueno, F. (coord); Bendala, E.; Grisolĩa, S.; López, M.A. (2006): La Gripe Aviaria: Un reto de salud pública, Universidad de Castilla La Mancha.

Carmona-González, N. (2015): "Recent Episodes on a Globalized Economy: An Historical Approach" in Díaz-Roldán, C. and Perote, J. (2015), 21-38.

Castells, M. (2000): La era de la información. Economía, sociedad y cultura. Vol. 1. La sociedad red, Alianza, Madrid.

Chavers, L.S., Vermund, S.H. (2007): "An Introduction to Emerging and Reemerging Infectious Diseases. Emerging Infectious Diseases: Trends and Issues", Springer Publishing Company, New York, 3-24.

Christian, D. (2007): Mapas del tiempo. Una introducción a la Gran Historia, Crítica, Barcelona.

CDC 2019 (Centro para el Control y la Prevenciōn de enfermedades) https:// espanol.cdc.gov/flu/pandemic-resources/basics/index.html. Accessed 9 June 2020.

Conversi, D. (2010): “The Limits of Cultural Globalisation?”, Journal of Critical Globalisation Studies, 3, 36-59.

Correia, S., Luck, S.; Verner, E. (2020): "Pandemics Depress the Economy, Public Health Interventions Do Not: Evidence from the 1918 Flu”, MIT, $1-49$.

Deloitte (2020): El impacto económico de COVID-19. https://www2.deloitte. com/ec/es/pages/strategy/articles/el-impacto-economico-de-covid-19-nuevo-coronavirus-.html. Accessed 10 May 2020.

Díaz-Roldān, C. and Perote, J. (2015): Recent Developments on International Economics. In Díaz-Roldān, C. and Perote, J. (eds.): Advances on International Economics, Cambridge Scholars Publishing, chapter 1, 3-20. 
Dye, C., Boerma, T., Evans, D., Harries, A., Lienhardt, C., McManus, J., \& Pang, T. (2013): Informe sobre la salud en el mundo 2013: investigaciones para una cobertura sanitaria universal. Luxemburgo, Organizaciōn Mundial de la Salud.

Enciclopedia Barsa (1988) Encyclopaedia Britannica Publishers, México.

Farris, W. (1985): Population, Disease, and Land in Early Japan, 645-900. Harvard University Asia Centre, Harvard-Yenching Institute Monograph Series 24.

Federal Reserve Bank of St. Louis (2007): Economic Effects of the 1918 Influenza Pandemic Implications for a Modern-day Pandemic.

Frenk, J.; Gómez-Dantés, O. (2007): "La globalización y la nueva salud pública”, Salud pública de México, 49(2), 156-164.

Frieden, J. A. (2013): Capitalismo global. El trasfondo económico de la historia del siglo XX, Crítica, Barcelona.

García Delgado, J.L. (ed.): Economía española y pandemia, Editorial Civitas.

García, S. (2017): Tesis Doctoral: La Gripe de 1889-1890 Madrid. U. Complutense de Madrid. https://eprints.ucm.es/49190/1/T40388.pdf. Accessed 10 May 2020.

Gibbon, E. (1996): The History of the Decline and Fall of the Roman Empire, Reprint Edition.

González B.S. (2005): "La pandemia olvidada de 1918”. Revista de estudios Médico Humanísticos 14(14) pp.123-127.

Gonzalbes Cravioto, E. y García García, I. (2007): “La primera peste de los Antoninos (165-170). Una epidemia en la Roma Imperial”, Revista de Historia de la Medicina y de la Ciencia, vol. LIX, $n^{0}$ 1, 7-22.

Grmek, M. D. (1992): Historia del SIDA. Siglo XXI, México.

Guerra, F. (1986): "El efecto demográfico de las epidemias tras el descubrimiento de América”. Revista de Indias 177, 41-58.

Hays, J.N. (2005): Epidemics and Pandemics: Their Impacts on Human History, OMS.

History of the wars. Harvard University Press. 1935.

International Monetary Fund (october 2020): World Economic Outlook, The Great Lockdown: dissecting the economic effects

International Monetary Fund (April 2006): World Economic and Financial Surveys World Economic Outlook. Globalization and Inflation.

Langhorne, R. (2001): The Coming of Globalization. Its Evolution and Contemporary Consequences, Palgrave, Basingstoke.

Le Goff, J. (1982). Time, work, and culture in the Middle Ages. University of Chicago Press.

Le Roy Ladurie, E. (1973): “Un concept: I'unification microbienne du monde (XIV siēcle-XVII siècles”, Scheweiz Z. Geschichte, 23, 627-696.

Lowson, J. A. (1897). The Epidemic of Bubonic Plague in Hongkong, 1894. The Indian medical gazette, 32(2), 45-59. https://www.ncbi.nlm.nih.gov/ pmc/articles/PMC5148360/. Accessed 5 June 2020. 
McNeill, W. H. y McNeill, J. R. (2010): Las redes humanas. Una historia global del mundo, Crítica, Barcelona.

Maradona, J.A. (2010): Historia de las enfermedades infecciosas. Universidad de Oviedo, Asturias.

Maris, N. (2011):" The Impact of Influenza: A Global Perspective" in Miasma to Microscopes: The Russian Influenza Pandemic in Hamilton, Anthropology Publications. Paper 5, 30-39.

Murillo, G. (2011): "Recordando a la gripe española", Medicina Interna de México, Volumen 27, núm. 5, 463-466

Niebuhr, B.G. (1844): The History of Rome, Vol II https://web.archive.org/ web/20090306084324/http://socserv2.mcmaster.ca/ econ/ugcm/31l3/ niebuhr/RomHis02.pdf . Accessed 8 June 2020.

OECD (march 2020): "Coronavirus: The world Economy at Risk" http://www. oecd.org/coronavirus/es/. Accessed 8 June 2020.

OECD (2020), OECD Economic Outlook, Interim Report March 2020, OECD Publishing, Paris, https://doi.org/10.1787/7969896b-en. Accessed 15 May 2020

OECD (April 2020); Regulatory quality and COVID-19: Managing the risks and supporting the recovery http://www.oecd.org/coronavirus/policy-responses/ regulatory-quality-and-covid-19-managing-the-risks-and-supporting-therecovery-3f752e60/\#section-d1e137. Accessed 5 June 2020

OECD (April 2020): Evaluating the initial impact of COVID-19 containment measures on economic activity. https://read.oecd-ilibrary.org/ view/?ref=126_126496-evgsi2gmajktitle = Evaluating_the_initial_ impact_of_COVID-19_containment_measures_on_economic_activity. Accessed 8 June 2020

Porter, J. I. (Ed.). (2006): Classical pasts: the classical traditions of Greece and Rome, Princeton University Press.

Rigau Pérez, J. G. (1996). Enfermedad y poblacion: Introduccion a los problemas y metodos de la epidemiologia historica. Bulletin of the History of Medicine, 70(3), 560-561.

Robertson, R. (1990): "Mapping the global condition: Globalization as the central concept", Theory, Culture and Society, 7 (15), 15-30.

Robertson, R. (2005): Tres olas de globalizaciōn. Historia de una conciencia global, Alianza, Madrid.

Rosen, G. (2015): A history of public health, JHU Press.

Sales, J. (2020): “La plaga de Justinià segons el testimoni de Procopi”, Epidèmies i malalties contagioses a l'Edat Mitjana: documents, representacions artístiques i literàries, IRCVM.

Serrano Sanz, J. M. (2020): "La economía y la pandemia. El Cronista del Estado Social y Democrático de Derecho”, 86, 110-113.

Stiglitz, J.E. (2003): "El malestar en la globalizaciōn" Revista Internacional de Sociología, 34, pp. 216-229.

Smith, F. (1995): "The Russian Influenza in the United Kingdom 1889-1894. The Society for the Social History of Medicine", 8 (1), 55-73. 
Snowden, F (2019): Epidemics and Society. From the Black Death to the Present, Yale University Press.

Vågene, Å.J., Herbig, A.; Campana, M.G. (2018): "Salmonella Enterica Genomes from Victims of a Major Sixteenth-Century Epidemic in Mexico". Nat Ecol Evol 2, 520-528.

Walter S. (2020): "Why the Wealthy Fear Pandemics. The Coronavirus, like other Plagues before it, Could Shift the Balance between Rich and Poor", New York Times. https://www.nytimes.com/2020/04/09/opinion/sunday/ coronavirus-economy-history.html. Accessed 20 May 2020.

Werner, A., Werner, H., Goetschel, N. (1999): Les épidémies: un sursis permanent. Atlande, 50-63.

Wolfe, N., Dunavan, C. y Diamond, J. (2007): "Origins of Major Human Infectious Diseases". Nature 447, 279-283. 